NBER WORKING PAPER SERIES

\title{
WHY SHOULD WE CARE ABOUT CHILD LABOR? THE EDUCATION, LABOR MARKET, AND HEALTH CONSEQUENCES OF CHILD LABOR
}

\author{
Kathleen Beegle \\ Rakeev Dehejia \\ Roberta Gatti \\ Working Paper 10980 \\ http://www.nber.org/papers/w10980
NATIONAL BUREAU OF ECONOMIC RESEARCH
1050 Massachusetts Avenue
Cambridge, MA 02138 \\ December 2004
}

We thank Eric Edmonds, Andrew Foster, Caroline Hoxby, Adriana Lleras-Muney, Enrico Moretti, Debraj Ray, and Douglas Staiger for useful conversations, and thank seminar participants at the NBER Summer Institute, Columbia University, the NEUDC 2003 conference, the World Bank, and New York University for comments. Denis Nikitin provided valuable research assistance. Support from the World Bank's Research Committee is gratefully acknowledged. Dehejia thanks the Chazen Institute of International Business, Columbia University Graduate School of Business, for a summer research grant. The views expressed here are those of the author(s) and do not necessarily reflect those of the World Bank and its member countries or of the National Bureau of Economic Research.

(C) 2004 by Kathleen Beegle, Rajeev Dehejia, and Roberta Gatti. All rights reserved. Short sections of text, not to exceed two paragraphs, may be quoted without explicit permission provided that full credit, including (C) notice, is given to the source. 
Why Should We Care About Child Labor? The Education, Labor Market, and Health Consequences of Child Labor

Kathleen Beegle, Rajeev Dehejia, and Roberta Gatti

NBER Working Paper No. 10980

December 2004

JEL No. D19, J22, J82, O15, Q12

\section{ABSTRACT}

Although there is an extensive literature on the determinants of child labor and many initiatives aimed at combating it, there is limited evidence on the consequences of child labor on socioeconomic outcomes such as education, wages, and health. We evaluate the causal effect of child labor participation on these outcomes using panel data from Vietnam and an instrumental variables strategy. Five years subsequent to the child labor experience, we find significant negative impacts on school participation and educational attainment, but also find substantially higher earnings for those (young) adults who worked as children. We find no significant effects on health. Over a longer horizon, we estimate that from age 30 onward the forgone earnings attributable to lost schooling exceed any earnings gain associated with child labor and that the net present discounted value of child labor is positive for discount rates of 11.5 percent or higher. We show that child labor is prevalent among households likely to have higher borrowing costs, that are farther from schools, and whose adult members experienced negative returns to their own education. This evidence suggests that reducing child labor will require facilitating access to credit and will also require households to be forward looking.

Kathleen Beegle

1818 H Street NW

Washington, DC 20433

kbeegle@worldbank.org

Rajeev Dehejia

Department of Economics

Columbia University

$420 \mathrm{~W} .118^{\text {th }}$ Street

Room 1022

New York, NY 10027

and NBER

rd247@columbia.edu
Roberta Gatti

1818 H Street NW

Washington, DC 20433

rgatti@worldbank.org 


\section{Introduction}

We investigate the effect of child labor on subsequent school attendance, educational attainment, occupational choices, earnings, and health. We find that children who worked when they were young are significantly less likely to be attending school five years later and have a significantly lower level of educational attainment. However, we find that child labor leads to a greater probability of wage employment and to higher daily labor and farm earnings, which more than fully offset the foregone earnings attributable to reduced schooling. There do not appear to be significant health effects of child labor.

The question we examine is important for many reasons. The assumption that child labor is harmful to children's development underpins both the theoretical literature and the policy debate. For example, from the policy perspective, there is a general perception that the worldwide returns to eliminating child labor are very large (see International Labour Organization [ILO], 2003). However, the evidence that rigorously quantifies the consequences of child labor is limited. Both theoretically and empirically, it is not clear whether child labor substantially displaces schooling. In rural settings in developing countries (and more than 70 percent of child labor in developing countries is rural; ILO, 2002), both school and child labor tend to be low-intensity activities, in contrast to the sweatshops and full-time work that characterize child labor in the popular imagination and which have existed historically in some urban settings in North America and Europe (see Basu, 1999). Furthermore, even if child labor does disrupt schooling, it presumably also provides the child with labor market experience that subsequently could lead to increased earnings. Which effect dominates is an empirical matter. 
A growing empirical literature (reviewed in Section 2.1) analyzes the relationship between child labor and school attainment but, with a few exceptions, this literature examines the correlation, not the causal relationship, between these variables. There are many reasons to doubt a causal interpretation of the correlation between child labor and education. Households that resort to child labor presumably differ along an array of dimensions, both observable (education, wealth, occupation) and unobservable (social networks, concern for children, etc.), from those that do not. Even within households, children's ability is unobserved to the econometrician but observable to parents. To the extent that parents send their least (most) motivated children to work, this would generate a negative (positive) correlation between child labor and school attainment simply based on selection.

To our knowledge, this is the first paper simultaneously to examine education, labor market, and health outcomes within a causal framework. We use an instrumental variables strategy that addresses some of the limitations of previous work. Using data from rural households in Vietnam, we instrument for participation in child labor by using community shocks and rice prices, two variables that influence child labor but are plausibly exogenous with respect to household choices (we provide a detailed discussion of our empirical strategy in Section 4).

We find that, over the 5-year period spanned by our panel, the mean level of child labor leads to a 30 percent lower chance of being in school and a 6 percent decrease in educational attainment. Our indicators of health generally are not affected by child labor status. However, children who have experienced child labor are more likely to be working for wages five years later, and also have higher daily earnings (including both 
actual wages and estimated farm wages). These estimates are significant at standard levels. They suggest that the returns to work experience are higher than the returns to schooling and that, overall, child labor might amount to a net benefit for children, at least until early adulthood. Over a longer horizon, we find that returns to education increase with age, whereas returns to experience decline monotonically; the net present discounted value of child labor is positive for households with a discount rate of 11.5 percent or higher.

The paper is organized as follows. Section 2 provides a review of the literature. Section 3 describes the data. Section 4 outlines our empirical strategy. Section 5 presents our results on the consequences of child labor. Section 6 compares the magnitude of the loss from educational attainment with the gain in terms of earnings. Section 7 concludes.

\section{Literature Review}

\subsection{The Child Labor-Schooling Tradeoff}

There is an extensive literature that examines the tradeoff between child labor and schooling. In this section, we highlight a few of the existing results.

Patrinos and Psacharopoulos (1995) show that factors predicting an increase in child labor also predict reduced school attendance and an increased chance of grade repetition. The authors also estimate this relationship directly and show that child work is a significant predictor of age-grade distortion (see Patrinos and Psacharopoulos, 1997). Akabayashi and Psacharopoulos (1999) show that, in addition to school attainment, children's reading competence (as assessed by parents) decreases with child labor hours. 
Finally, Heady (2003) uses direct measures of reading and mathematics ability and finds a negative relationship between child labor and educational attainment in Ghana.

All of these papers examine the correlation, rather than the causal relationship, between child labor and schooling. As we discuss in detail below, there are many reasons to doubt that the two coincide. A few recent papers address this issue.

Using data from Ghana, Boozer and Suri (2001) exploit regional variation in the pattern of rainfall as a source of exogenous variation in child labor. They find that a one hour increase in child labor leads to a 0.38 hour decrease in contemporaneous schooling. Cavalieri (2002) uses propensity score matching and finds a significant, negative effect of child labor on educational performance. Ray and Lancaster (2003) instrument child labor with household measures of income, assets, and infrastructure (water, telephone, and electricity) to analyze its effect on several school outcome variables in seven countries. Their findings generally indicate a negative impact of child labor on school outcomes. ${ }^{1}$ However, their two-stage strategy is questionable, because it relies on the strong assumption that household income, assets, and infrastructure satisfy the exclusion restriction in the schooling equations. Finally, Ravallion and Wodon (2000) indirectly assess this relationship in their study of a food-for-school program in Bangladesh that exploits between-village variation in program participation. They find that the program led to a significant increase in schooling, but only one-eighth to one-quarter of the increased hours of schooling were attributable to decreased child labor. This suggests that child labor does not lead to a one-for-one reduction in schooling.

\footnotetext{
${ }^{1}$ In some cases they find the marginal impact of child labor to be positive. In particular, for Sri Lanka, the impact is positive for all schooling outcomes.
} 
The link between child labor and subsequent labor market outcomes is examined by Emerson and Souza (2002). They show that, controlling for family background and cohort, early exposure to child labor significantly reduces earnings, but that no significant effect emerges for adolescents (which is closer to the age range that we examine). However, these authors do not address the endogenous choice to enter into child labor; thus, their findings cannot be interpreted causally.

In this paper, we make two contributions beyond these studies. First, we use instrumental variables and household fixed effects to try to address the selection biases that emerge in child labor studies. Although no identification strategy is perfect in an observational study, we believe that our use of these two methods produces a plausible range of estimates. Second, we examine both education and labor market outcomes, which allow us to address the key question in this paper: whether the net effect of child labor is positive or negative. We also consider the health consequences of child labor.

\subsection{The Returns to Schooling}

In order to compare the effect of child labor on schooling with the effect on labor market outcomes, we require an estimate of the returns to schooling. A vast literature exists on this subject. Psacharopoulos and Patrinos (2002) summarize a range of studies that focus on individual wage earnings (i.e., excluding returns to education in self-employment or returns associated with labor contributions to family businesses and farms). They find that the returns to education tend to be higher in developing countries than in developed countries. For Asian countries, the authors estimate a 10 percent rate of return to a year in 
school, compared to 7.5 percent for OECD countries and 12 percent for Latin America and the Caribbean.

Of course, it is also useful to compare these estimates to those from the standard studies for the United States that use quasi-experimental data (e.g., Angrist, 1990; Ashenfelter and Krueger, 1994; and Ashenfelter and Rouse, 1998). These studies produce estimates on the order of a 10 percent return to a year of schooling.

For Vietnam, a recent paper by Moock et al. (2003) finds that an additional year of schooling is associated with a 5 percent increase in earnings.

\subsection{Existing Research on Vietnam}

The rapid economic growth in Vietnam in the 1990s has been characterized by a decline in both the incidence and intensity of child labor (see Rosati and Tzannatos, 2004, for a description of these trends). Edmonds and Turk (2003) document the sharp decline in child labor in the 1990s, and they link this decline to significantly improved living standards. In particular, Edmonds (2003) and Edmonds and Pavcnik (2003) examine the effect that the integration of Vietnam's rice market had on child and adult labor markets. They find that the increase in rice prices between 1992-93 and 1997-98 was associated with reduced child labor. This result motivates the first stage of our two-stage least squares procedure. O’Donnell et al. (2003) investigate the impact of child labor on health outcomes for children in Vietnam. Using instrumental variables, they find some evidence that work during childhood has a negative impact on health outcomes five years later. We discuss their results further in Section 5.6. 
Finally, in terms of the rural labor market and returns to schooling, Glewwe and Jacoby (1998) note that it may not be efficient to keep productive family members in school. The evidence suggests that primary schooling raises productivity in agriculture, whereas secondary schooling does not provide additional productivity gains. ${ }^{2}$

\section{Data Description}

We use data from the Vietnam Living Standards Survey (VLSS), a household survey that was conducted in 1992-93 and again in 1997-98. Both surveys were conducted by Vietnam's General Statistics Office (see www.worldbank.org/lsms). Of the 4,800 households interviewed in 1992-93, about 4,300 were re-interviewed in 1997-98. The surveys contain information on household composition, time use for children, educational attainment, and labor market activities of household members. In conjunction with the household survey, a community survey was conducted in rural communes to gather information such as the presence of schools, roads, electricity, local rice prices, and the occurrence of disasters in the community. For this paper, we use information on the panel of rural households with children between the ages of 8 and 13 at the time of the 1992-93 survey.

We use two measures of children's subsequent human capital. School attendance, which is measured dichotomously, is an input in the formation of human capital and, as such, only a distant proxy for the outcome of interest, the accumulation of knowledge. However, existing evidence (see for example King et al., 1999) suggests that attendance co-varies quite substantially with child labor (that is, working children attend school less

\footnotetext{
${ }^{2}$ At the same time, the tradeoff to reduced schooling would be increased experience in working on the family farm which may have significant benefits (see, for example, Rosenzweig and Wolpin, 1985).
} 
regularly than non-working children) and appears to be a better measure of time in school than, say, enrollment. We also use highest grade attained as an outcome, which is an output measure of the schooling process instead.

We have three measures of children's subsequent earnings. We observe whether children are working for wages outside the household and their daily labor market earnings from this work. To account for the large share of individuals who have zero market earnings (as expected in a sample of rural households), we use detailed information on farm outputs and inputs to estimate marginal productivity of labor by age and gender categories (see the Appendix and Jacoby, 1993, for details). The marginal productivities are a measure of shadow wages for those with no observed market wage. We then use this shadow wage estimate as the unobserved wage for those respondents who are not working in the labor market.

Table 1 provides an overview of our data. Of the 2,133 children between the ages of 8 and 13 in our sample, 640 worked in the first round of the survey. We measure child labor hours as the total hours the child was engaged in income-generating work, including work on the family business or farm. The majority of children working in either the first survey (1992-93) or the follow-up survey (1997-98) were working as unpaid family labor in agriculture or non-agricultural businesses run by the household. ${ }^{3}$ The average work intensity is 7 hours per week, but among children who work it is 24 hours per week. The gender distribution of working children is balanced. Parental

\footnotetext{
${ }^{3}$ The concept of child labor (by ILO standards) does not necessarily refer to simply any work done by a child, but, rather, to work that stunts or limits the child's development or puts the child at risk. However, in household survey data it is difficult (perhaps impossible) to appropriately isolate the portion of time spent working on the farm that qualifies under this very nuanced definition.
} 
education is higher and per capita expenditure is lower in households where children work.

The middle section of the table summarizes the two instruments we use to identify the decision to send a child to work: community-level rice prices and community disasters (storms, floods, drought, pest attacks) in 1992-93. There is substantial variation in both rice prices and shocks in 1992-93. As noted in Benjamin and Brandt (2003) and Edmonds and Pavcnik (2003), the variation in rice prices in 1992-93 stems from the restrictions of rice sale across communities prior to 1997. Neither rice prices nor incidence of community disasters appear to be unconditionally correlated with child labor. However, these are highly significant predictors of child labor in a regression framework.

Finally, Table 1 summarizes the outcomes of interest. In the second survey round, 64 percent of children are in school overall, but the rate of school attendance is 8 percentage points higher among non-working children than among those who work. Though there tend to be more schools in villages where children do not work, we find that the schooling-child labor relationship is significant even after controlling for this difference. The level of educational attainment is higher among working children. Finally, we note that children who work in the first round do not appear to be more likely to be working for a wage by 1997-98; market earnings are only slightly higher; and estimated wage per day is lower. ${ }^{4}$

\footnotetext{
${ }^{4}$ Two features of the data are worth noting. First, one might be concerned that children more (or less) likely to be working in the second round are more likely to drop out of the sample. However, Edmonds and Turk (2003) find this problem not to be severe. Secondly, as noted in Edmonds and Pavcnik (2003), the
} 


\section{Empirical Framework}

In this section we outline the framework we use to identify the effect of child labor on a range of subsequent child outcomes.

\subsection{Base Specification and Sample Restrictions}

The treatment in our analysis is defined as having participated in child labor in the first round of the survey, $T_{i}$. The outcomes $\left(Y_{i}\right)$ of interest (school enrollment, highest grade completed, occupation, earnings, and health) are measured five years later. Thus our basic specification is of the form:

$$
Y_{i, t+5}=\alpha+\beta T_{i, t}+\gamma X_{i, t}+\varepsilon_{i, t+5}
$$

where $X_{i}$ are household and community-level controls. We impose several restrictions on the sample that we examine. First, we consider children between the ages of 8 and 13 . The prevalence of labor among younger children is low. Likewise, by some definitions, labor at age 14 and above would not be viewed as a particularly serious form of child labor. Second, we restrict the sample to those children who were in school during the first round of interviews. If we were to include children who were not in school during round one, we also would have to include the school attendance variable in equation (1) above, which then would create additional problems of identification (namely, identifying the separate effects of schooling and child labor in round one on outcomes in round two). Instead, we identify the effect of child labor among those children who were in school in round one (1992-93).

form of the child labor question changed between the two surveys. However, since our child labor treatment occurs in the first survey round this is not a concern in our framework. 
Two potential sources of selection bias exist in estimating equation (1) using OLS: between-household selection (that is, which types of households opt into child labor) and within-household selection (that is, which children parents select to work more or less). ${ }^{5}$ To address the first, we control for a range of household characteristics, including parental education and household expenditure in round one; of course, omitted household characteristics that determine participation in child labor and that affect educational choices remain a concern. It is inherently more difficult to control for within-household differences among children, since our dataset does not include child-level ability measures. We address both sources of bias by using an instrumental variables strategy.

\subsection{Instrumental Variables}

Our instrumental variables specification is:

$$
\begin{gathered}
T_{i, t}=\mathrm{a}+\mathrm{b} Z_{i, t}+\mathrm{c} X_{i, t}+v_{i, t} \\
Y_{i, t+5}=\alpha+\beta \hat{T}_{i, t}+\not X_{i, t}+\varepsilon_{i, t+5}
\end{gathered}
$$

where in equation (3) we make the necessary two-stage least squares adjustments.

The ideal instrument is one that induces variation in child labor (i.e., is "relevant"), that is exogenous, and that affects the outcome of interest (e.g., schooling and wages) solely through the child labor participation decision (i.e., is "excluded"). We consider two instruments: rice prices and community disasters (both measured at the commune level in the first survey round). We discuss the plausibility of each instrument in turn.

\footnotetext{
${ }^{5}$ See Horowitz and Wang (2004), who build a model around within-household heterogeneity among children. In our empirical results, a comparison of our OLS and IV estimates will shed some light on this issue.
} 


\subsubsection{Rice Prices}

The timing of the two rounds of our survey (1992-93 and 1997-98) provides us with a source of variation in the use of child labor that is unique to Vietnam, namely community rice prices (see Edmonds and Pavcnik, 2003). Prior to 1997, the inter-commune rice market in Vietnam was heavily regulated, with the sale of rice among communes facing restrictions comparable to international rice exports. This created substantial variation in rice prices, which we argue is relevant to child labor and exogenous. After 1997, trade in rice across communes was liberalized. As a result, rice prices in the second survey round are not significantly correlated with rice prices in round one; this supports our claim that 1993 rice prices are plausibly excluded from our outcome equation in round two. We consider the issues of relevance, exogeneity, and exclusion in turn.

Regarding relevance, rice prices potentially affect both the demand for and the supply of child labor. ${ }^{6}$ Higher rice prices could lead to the decision to cultivate more rice, and hence increase the demand for child labor. Higher rice prices also would have an income effect on rice-producing households, leading households to reduce the supply of child labor. For our purposes, which effect dominates does not matter, as long as rice prices are relevant for determining child labor decisions.

As for exogeneity, since rice prices are determined at the commune level in round one and outcomes are determined at the household level in round two, it is unlikely that there is a direct reverse causation. The concern is instead the possibility of omitted variable bias, namely whether community rice prices in 1993 will be correlated with

\footnotetext{
${ }^{6}$ See the discussion in Edmonds and Pavcnik (2003) and Kruger (2002). For example, Kruger (2002) finds a positive effect of coffee prices on child labor in Nicaragua.
} 
unobservable variables that could confound a causal interpretation of the effect of child labor five years later. However, mobility (and migration) of households across communes was limited in 1993, and there is no evidence that households sort themselves across communities based on their attitudes toward child labor (we show this in Section 5.2 below). Both of these arguments suggest that we have no reason to expect community rice prices to be correlated with omitted variables that predict child labor, and hence that rice prices are exogenous with respect to child labor decisions.

The validity of the exclusion restriction regarding rice prices requires more thought. The lack of correlation between rice prices across rounds provides prima facie evidence that rice prices are transitory during this period in Vietnam. We further strengthen this argument by controlling for rice prices in 1998 in our regressions. Nonetheless, two concerns remain. Rice prices are presumably the result of a demandsupply equilibrium within each commune, and as such might reflect structural features of the commune that could continue to affect schooling and labor decisions five years later. We address this concern by controlling for a range of structural factors that affect demand and supply (including population, income, and agricultural technology). Rice prices in 1993 could also affect outcomes in 1998 through other factors that have a persistent effect on households across rounds (e.g., household income growth or wealth). We address this concern by assessing whether 1993 rice prices predict wealth or income growth in round two. 


\subsubsection{Community Disasters}

Community shocks affect child labor through two channels: from the demand side through a shock to production technology, and from the supply size via income effects at the household level. Depending on the nature of the shock, these effects could go in opposite directions, though we will see in the data that they do not cancel out and that the net effect is positive and large. Furthermore, since these shocks are natural disasters, they are exogenous to household decisions (there is no evidence that households migrate on the basis of susceptibility to shocks). We expect disasters to have differential impacts in poorer and richer households; to capture this, we add to our list of instruments the interaction of our crop-shock instrument with log per capita household expenditure in 1992-93.

As with rice prices, the chief concern is the exclusion restriction, in particular the mechanisms (other than child labor) through which the effect of shocks could persist. To bolster the credibility of the instrument, we show that community disasters are transitory, and also investigate whether they have a persistent effect on household wealth.

\subsection{Fixed Effects}

As a final robustness check, we will also present household fixed effects estimates:

$$
Y_{i, t+5}=\alpha_{h}+\beta T_{i, t}+\not X_{i, t+5}+\varepsilon_{i, t+5}
$$

When comparing the two estimators, in principle, the instrumental variables approach addresses both potential sources of bias (between- and within-household selection), but also potentially exposes us to misspecification error if the instruments are invalid. In 
contrast, household fixed effects correct only for the first source of bias, but are less exposed to misspecification. We present both sets of results below.

\section{Results}

\section{$5.1 \quad O L S$}

We begin by briefly discussing the OLS relationship between child labor and our outcomes. Although we do not believe that these estimates are causal, they are a useful reference point for our subsequent instrumental variables results. In looking at the first row of Table 2, we note that child labor in the first round is significantly associated with only one of the outcomes we examine (in school). More child labor is associated with lower attendance, an increased likelihood of wage work, higher market earnings per day, and higher wage per day. Surprisingly, more child labor is associated with higher school attainment. However the effect is not significant. Both mother's and father's education are positively and significantly associated with enrollment and educational attainment. A higher level of per capita household expenditure is associated with a higher enrollment probability and a higher grade completed. It is negatively associated with the probability of being engaged in wage work and with market earnings per day, but positively associated with wage per day. Given the many selection problems with these results, we do not attempt to interpret them further.

\subsection{Instruments: Relevance and Exclusion}

In Table 3 we present the first stage of our instrumental variables regression. Column (1) reports our basic specification, with community disasters, rice prices, and community 
disasters interacted with log per capita household expenditure as our instrument set. These instruments are, individually, highly significant (see also Edmonds and Pavcnik, 2003). A community disaster is associated with an increased use of child labor, and rice prices are associated with reduced child labor. Moreover, the increased use of child labor associated with community disasters is significantly smaller among households with higher per capita expenditure. The instruments are jointly significant, with an F-statistic of 9.07 (a p-value of less than 0.00005).

In columns (2) and (3) we present two alternative specifications which we also use below. In column (2) we control for rice prices in 1997-98, because this increases the plausibility that rice prices in 1992-93 satisfy the exclusion restriction. The effect of the instruments is virtually unchanged in either magnitude or significance. Finally, we include additional community controls - population, distance to roads, electrification, and number of tractors - because these are potentially relevant for selection into child labor. The coefficients on the instruments are virtually unchanged, and the instrument set remains jointly significant.

Having established that the instruments we use have power in the first-stage, we next consider the plausibility of satisfying the exclusion restriction. In particular, our concern is that the instruments may be correlated with an omitted variable. For example, community shocks could reduce household wealth and consequently also belong in the second-stage regression. Likewise, rice prices are related to agricultural production, which could be correlated with community attitudes toward child labor. Rice prices could also drive changes in household income. Although it is not possible to test the 
validity of the instruments with respect to all of the potentially excluded variables, we can examine their correlation with a range of relevant variables that are observed.

In Table 4 column (1), we consider whether rice prices and community disasters in the first survey round predict the future occurrence of shocks (see Morduch, 1994). Neither instrument is significant. In column (2) we consider whether the instruments are correlated with the presence of secondary schools within communities - which may reflect a preference for education - and find no significant effect. In column (3), there is no evidence that the value of durable assets (a measure of wealth) in the second survey round is correlated with the occurrence of community disasters (and rice prices) in the first survey round. This suggests that correlation between community disasters and household wealth should not explain away our results regarding the effect of child labor on schooling. In columns (4) and (5) we confirm that the instruments are not correlated with the incidence of illness among children in the previous month or previous 12 months. In particular, if rice prices were correlated with community-level attitudes toward children's welfare, then we might expect to find not only a greater use of child labor but also worse health. We do not find evidence of this.

Finally, in column (6) we examine whether either of the instruments predicts growth in per capita expenditure at the household level. If rice prices were to significantly predict household expenditure, this would suggest that commune-level rice prices are associated with some structural feature of the community (e.g., agricultural productivity or quality of infrastructure) and thereby violate the exclusion restriction. We do not find any significant relationship. 
Overall, these results support the use of rice prices and community disasters as instruments for child labor.

\subsection{Instruments: Robustness}

In this section we present several versions of our basic instrumental variables estimator applied to the indicator for school attendance in 1997-98. In subsequent sections, we will examine a range of outcomes, but here we are interested only in examining the robustness of our estimator to alternative specifications of the instrumental variables.

In Table 5 column (1) we present our main results, using as instruments community shocks, community shocks interacted with household expenditure, and rice prices. The effect of child labor is negative, significant at the 1 percent level, and large in magnitude: relative to a mean level of attendance of 63 percent, the mean level of child labor (7 hours) leads to a 30 percent decrease in the probability of attendance. In columns (2) to (4), we rotate the instruments, first using only rice prices, then only community disasters, and finally just prices and community disasters (dropping the interaction term). Overall, our key result is robust in magnitude across these specifications. The estimated effect is substantially larger in column (3), but we lose precision in the estimates without the full set of instruments.

Given that we have more than one instrument, we can subject our set of instruments to a test of over-identifying restrictions. Our specification passes the test with a p-value of 0.24 and 0.29 . 


\subsection{Main Results}

In Table 6, column (1), we again present our benchmark result for school attendance. Working as a child during the first survey round leads to a significantly lower level of school attendance five years later. As noted earlier, the mean level of child labor leads to a 30 percent reduction in the proportion of children attending school. In column (2) we show results for highest grade completed. We see that the effect is negative and significant at the 10 percent level; children who worked in the baseline survey have a significantly lower level of educational attainment. The magnitude is significant as well: a mean level of child labor leads to a 6 percent decrease, relative to the mean, in educational attainment. $^{7}$

In columns (3) to (5) we examine the impact of child labor on occupational choice and earnings. In column (3), the effect of child labor on the proportion of respondents who are wage workers in the second round of the survey is positive and significant at the 10 percent level: at the mean level of work, child labor leads to a 64 percent increase in the likelihood of being a wage worker in the second survey round. The effect of child labor on labor market earnings also is positive and significant at the 10 percent level (column (4)). A concern with this result is that some of the children in the second survey round are still in school. In column (5) we address this by focusing on individuals age 17 and older, who are less likely still to be attending school. Even among this group, we find a large and significant effect of child labor. The magnitude of the coefficient is substantial: at a mean level of work, child labor is associated with a doubling in labor

\footnotetext{
${ }^{7}$ Results are similar when, instead of working hours, total hours in both economic work and household chores are the measure of child labor in the regression. In the sample, children average six hours of chores per week (ten for children who do chores). Girls' chores average 1.5 hours more per week than boys - a
} 
market earnings, capturing both the reduction in school attendance and an increased wage rate. This result is robust to controlling for age, both linearly and non-linearly.

The results in columns (4) and (5) focus on market earnings, but as was noted in Section 3, only about 6 percent of the sample is participating in the labor market. To provide a more comprehensive measure of earnings, in column (6) we use wages per day, combining market earnings with estimated farm wages. We find a positive effect, significant at the one percent level; at the mean level of work, child labor leads to a 42 percent increase in estimated wages per day.

It is interesting to note that the IV estimates are larger than the OLS estimates. To the extent that families send the less academically gifted children to work (and child ability is unobservable), OLS should overestimate the impact of child labor on schooling relative to the causal effect (as estimated by IV). Our results instead support the view that families send their more academically gifted children to work (possibly because they are also more productive), which validates one of the key predictions of the model presented in Horowitz and Wang (2004).

In Table 7 we examine the heterogeneity of the treatment effect at different levels of work intensity. The treatment is an indicator of having worked more than a given percentile of the child-labor work-hours distribution. In particular, we examine the effect at the median, at the $75^{\text {th }}$ percentile, and at the $90^{\text {th }}$ percentile. The effect of having worked more than the median (zero hours) is not statistically significant for most outcomes (wages per day is the exception). Nonetheless, the magnitudes are large: for example, highest grade attained is more than 3 years lower for children who worked. The 
impact of having worked more than the 75 th percentile (more than 12 hours per week) is significant at the 10 percent level for the education outcomes and wages per day. Finally, when the treatment is defined as having worked more than the $90^{\text {th }}$ percentile $(28$ hours per week), all of the treatment effects are significant. Except for school attendance, the magnitudes of the results are similar across the three definitions of child labor. This suggests that though much of the precision of our estimates comes from the upper end of the child labor distribution, the magnitude of the effect depends on having worked as a child rather than on the intensity of work.

\subsection{Robustness of the Results and Instruments}

The causal interpretation of the results presented in the previous section relies on the validity of the instruments. In this section, we explore - and try to rule out - a range of arguments against our instruments.

One concern with using rice prices as an instrument is that villages with higher rice prices in 1992-93 might simply have a higher overall price level, which would automatically lead to higher child earnings from wage work. We confirm in Table 8, column (1), that children who worked in 1992-93 have higher earnings in 1997-98, even when earnings are normalized by rice prices. The effect is significant at the 1 percent level and comparable in magnitude to previous results.

Another potential problem is that Southern Vietnam is a rice-growing (and rice surplus) region, whereas Northern Vietnam is a rice deficit region. In 1992-93, there were severe restrictions to trade across regions, which led to lower rice prices in the South than the North. This leads to two concerns. First, if low rice price (high child labor) areas 
experienced relatively more rapid development of their labor markets, then this could explain the results for wage increases among children who were working in the first survey round. To test for this, we use our base specification to estimate the effect of adult work on adult earnings five years later. If the child wage result were simply due to a labor market effect, then we would expect to find a similar result for adults. However, we do not find any such effect (column (2)). Second, North and South could differ in their levels of, and attitudes toward, education and child labor. We test for this by restricting our sample to communities in the North. These results are presented in columns (3) to (5) for our main outcomes, and are similar in sign and significance to our base results.

More generally, we are concerned that the instruments may not be excluded from the outcome equations. As discussed in Section 4.2, we address this concern by controlling for a range of structural variables that could drive price differences. ${ }^{8}$ To account for community factors driving the demand for rice, we control for population (in addition to household per capita expenditure which accounts as well for betweencommune differences in levels of expenditures). On the supply side of rice, we control for variables related to technology, including village electrification, presence of roads, and use of tractors. Finally, we control for rice prices in 1997-98 to remove any remaining correlation between 1993 rice prices and outcomes in 1998. Our results are presented in columns (6) to (8). For highest grade attained, market earnings per day, and wages per day, the estimated coefficients are comparable in sign and magnitude to those in Table 6 . The coefficients are still significant at standard levels, though standard errors increase somewhat. 
As a final robustness check, in Table 9, we present household fixed effects results. Although these results do not correct for within-household selection, they do correct for time-invariant between-household selection and are not exposed to potential misspecification of the instruments. In Table 9, we see that the results are qualitatively similar to those in Table 6, although the magnitudes are smaller. Child labor has a negative and significant effect on school attendance; the educational attainment results point in the same direction as Table 6 , though are not significant. The results for wage work and market earnings are positive and significant, although smaller in magnitude than Table 6. Finally, for wages per day we find a positive and significant effect. The fact that fixed effects estimates are smaller than our IV estimates suggests that withinhousehold selection biases our results downward, in particular that parents select their most able children to work.

\subsection{Health Effects}

Beyond the intrinsic importance of health for well-being, improved health status is widely recognized to lead to greater economic productivity (Strauss and Thomas, 1995), and can interact with school performance (see, for example, Glewwe et al., 2001, and Alderman et al., 2001). The existence of a significant health effect could offset (or reinforce) a trade-off between child labor and subsequent well-being. In particular, worse health could offset some of the gains from increased labor market earnings that were noted in Section 5.4. In this section, we examine the effect of child labor on subsequent health outcomes.

\footnotetext{
${ }^{8}$ For agricultural shocks, it is worth noting that community shocks occur in the 12 months prior to the first interview. Thus, when we control for log per capita household consumption in the baseline survey, we are
} 
As with schooling, there is no single, satisfactory indicator of health. We use two self-reported measures and a physical assessment. For the former, we first examine an indicator of whether the individual had any illness in the previous four weeks, ranging from headaches and cough to fever, diarrhea, and infection. The second health measure is the number of days the individual suffered from any of these illnesses in the previous four weeks if sick. Body mass index (BMI), an indicator of current nutritional status, is computed as weight in kilograms divided by squared height in meters. This measure has been found to be associated with physical health and to be positively related to productivity and earnings.

We present our estimates in Table 10. Column (1) shows that the probability of illness is not significantly associated with child work. In column (2) we see that the number of days ill among those who have been ill does not significantly increase with child labor. These results differ somehow from those reported by O' Donnell et al. (2003) who find in a bivariate probit specification that child labor is associated with a higher likelihood of a recent illness five years later. A number of factors can explain this difference. First, we measure the intensity of child labor (hours a child worked in the seven days preceding the household survey interview). O’ Donnell et al. (2003) instead use an indicator for any child labor in the previous 12 months. ${ }^{9}$ More importantly, our results identify the effect of child labor on health only among children who were in school in 1993. As discussed above, this allows us to abstract from the issue that child labor can affect contemporaneous schooling decisions. In turn, schooling might affect

\footnotetext{
controlling for the wealth effects that could result from the shocks.

${ }^{9}$ Note though that this difference is unlikely to account for the contrast in our results, because the two variables are highly correlated, with an overall correlation of 0.63 .
} 
health in the following survey round, in which case O' Donnell et al. (2003) are estimating a child labor-cum-education effect, while we identify a pure child labor effect. Similarly to O'Donnell et al. (2003), we find no significant impact of child labor on growth (column (3)).

It should be noted that we observe a limited range of health outcomes.

Nonetheless, because the evidence is not significant overall, we will set aside the health consequences of child labor in the next section when we compare the economic costs and benefits of child labor.

\section{Discussion and Extensions}

\subsection{The Net Cost of Child Labor: Static Analysis}

In this section we present a highly simplified calculation of the net economic cost of child labor. We compare the cost of child labor in terms of foregone schooling with the benefit of child labor in terms of earnings five years later.

Several caveats should be emphasized. First, parents (and children) presumably are forward-looking in their schooling and child-labor decisions. But our estimates of the returns to schooling are based on the contemporaneous experience of parents, which may be problematic in evaluating the value of education for children in a transition economy. Second, both the returns to education and the direct benefits of child labor experience may vary over the lifecycle. In this section, we present a static comparison at the fiveyear horizon. In Section 6.2, we use adults' labor market experience to extrapolate the costs and benefits of child labor over a longer horizon. Third, although we found no 
systematic evidence of any health costs of child labor in Section 5.6, such costs may exist along other dimensions.

Finally, there are several challenges in identifying the returns to schooling. In Section 6.2 we will use data on adults in the baseline survey to estimate dynamic profiles of returns to schooling and experience. In this section we instead use existing estimates for Vietnam from Moock et al. (2003). They find that private returns to education are relatively low. An additional year of schooling is associated with a 5 percent increase in earnings. Males have a lower return ( 3 percent) than females ( 7 percent). These returns are lower than those typically observed in low-income economies, but are consistent with transition economies where limited market reforms may not yet have resulted in higher returns to schooling.

Based on the results in Table 6, a mean level of child labor (7 hours) leads to a decrease in educational attainment of half a year. This reduction in schooling in turn implies future earnings that are 2.5 percent lower. On the other hand, an increase in hours worked in 1992-93 is associated with an increase in market earnings that is double relative to the mean and with a 40 percent increase in wages per day. Thus, an increase in child labor leads five years later to a substantial net increase in earnings per day. We also reach a qualitatively similar conclusion based on our fixed effects estimates in Table 9, although the magnitudes are smaller.

It is notable that our key finding would not be overturned if we assume a much higher return to education, even returns on the order of 10 to 15 percent or higher for example. Furthermore, if the private costs of education are factored in, then the private returns to schooling are lower than the returns we used above. Moock et al. (2003) 
conclude that secondary education did not appear to be a good investment in terms of future wage earnings in 1992-93. Glewwe and Jacoby (1998) draw a similar conclusion with regard to agriculture, where secondary schooling does not provide additional productivity gains.

\subsection{The Dynamic Returns to Schooling and Experience}

In the previous section, we examined the costs and benefits of child labor at a five-year horizon. In this section, we estimate the age profile of the returns to schooling and experience, and then examine the net benefit of child labor over a longer time horizon. In order to do this, we assume that as the children in the sample age, they will face an age profile of returns to schooling and experience similar to the current adults in the sample and that children (or parents on their behalf) use the labor market experience of adults as a guide in making their schooling and child labor decisions.

We begin by estimating the age profile of the returns to schooling and experience for the adults in our sample using 1997-98 data (Table 11). We regress market earnings and wages per day on education, age and age squared, and the interaction of age and education and also include household fixed effects (columns (3) and (4)). The education and experience effects are plotted in Figures 1 and 2. For market earnings, we find that the returns to education begin negative and reach a maximum between ages 45 and 48 (depending on the specification) and then decline slightly thereafter. The effect of experience (age) instead decreases monotonically. For wages per day, the returns to education increase until age 51 or 52 , and then decline slightly thereafter. The returns to experience decline monotonically. Comparing Figures 1 and 2, the education effect is 
relatively more important for market earnings than for wages per day; the latter includes farm work, for which experience is presumably more important than education when compared to market work.

We use these estimates to generate a profile of earnings under two scenarios. First, we use the estimates from column (4) to predict wages per day for an individual with a typical level of education (6.88 years, the mean of our adult sample). This is the darker line in Figure 3. We compare this to an individual who worked an extra 7 hours as a child (which is the mean level of child labor in our sample). Based on the estimates in Table 6, we know that such an individual's schooling would be 6 percent lower, but earnings would be 40 percent higher. We use the latter as a one-time upward shift in the level of earnings, and based on the former, we use an average level of education of 6.1 years to predict an age profile. Finally, we assume that the experience effect of child labor follows the same age profile as the overall experience effect illustrated in Figure 2.

The age profile of earnings for an individual who worked 7 hours per week as a child starts out significantly higher, but decreases more rapidly than that for an individual who did not work. The cross-over point is age 30. In present discounted value terms, the net benefits of child labor are positive for discount rates of 11.5 percent or higher. In terms of the range of interest rates available to rural households in Vietnam, 11.5 percent is on the low end of the spectrum. Microcredit organizations seem to offer interest rates between 12 and 14 percent per annum, which are below market compared to other sources of informal credit. ${ }^{10}$ This suggests that, except for individuals with access to

\footnotetext{
${ }^{10}$ For example, the Vietnam Bank for the Poor charges an interest rate of 1.2 percent per month (see http://www.gdrc.org/icm/country/viet-vbp.html). The Vietnam Bank for Agriculture charges an interest rate of 1.75 percent per month (see http://www.gdrc.org/icm/viet-dat_tran.html). The World Bank's Mobile Banking Program charges an interest rate of 12 percent per annum (see http://www.imf.org/external/pubs/ft
} 
credit at low interest rates, incremental child labor has a positive net present discounted value.

Figure 3 illustrates one of the key tradeoffs of child labor. Although the returns to education eventually dominate any gains from child labor experience, the payoff to education is realized only ten or more years after the earnings benefits of child labor.

\subsection{Why Do We Observe Child Labor?}

In the previous sections we argued that the returns to child labor are substantially positive at a five-year horizon, and possibly much longer. This naturally leads to the question: why do some households choose to send their children to work and not others? We consider a range of theories.

First, we consider the most obvious theory based on our results: that households who face a lower discount rate are less likely to resort to child labor. We use household wealth (log per capita durable assets and household expenditures) as a proxy for a household's ability to borrow (for example, see Beegle et al., 2003; Jacoby, 1994; and Zeldes, 1989). Second, we consider a behavioral theory: that parents use their own experience (i.e., returns to education ${ }^{11}$ ) in the labor market to decide whether to send their children to work. ${ }^{12}$ Third, we examine the effect of landowning, with the view that

\footnotetext{
/fandd/2004/06/pdf/hung.pdf). The Vietnamese-Belgian Credit Project provides loans at 12 percent per annum (see http://www2.btcctb.org/vietnam/micro-finance.htm).

${ }^{11}$ Using the specification in Table 11, we estimate the market returns to schooling in 1992-93 for adult members of households who have children in round one. These estimates measure the correlation between adults' education and earnings, not necessarily the causal effect. This is appropriate if adults use their own experience of the returns to education, without disentangling what portion of their returns to schooling is causal and what portion is attributable to factors such as ability.

${ }^{12}$ The role of experience in economic decision making is discussed in many contexts. Ray (1998) notes that it may take several generations before the sharp and unprecedented decline in mortality is incorporated into optimal fertility decisions. In a similar sense, though rates of returns to education may be increasing as a country develops, parents may still use their own experience in making schooling decisions for their
} 
landowning households could have a greater demand for child labor. Finally, we examine whether households for whom it is more costly to send children to school (using distance from the nearest school as a proxy for this cost) are more likely to use child labor.

The results are presented in Table 12. In column (1), we show that households in which the adults experienced negative returns to education are significantly (5.4 percent) more likely to use child labor; this effect is significant at the 10 percent level. We find that child labor increases significantly with household size. Household wealth has a negative effect on child labor, significant at the 1 percent level. A one standard deviation increase in per capita household wealth leads to a 5.6 percentage point reduction in the likelihood of child labor. In column (2), we introduce an additional measure of household wealth, log per capita expenditure. Since the two measures of household wealth are highly correlated (a correlation coefficient of 0.7 ), it is not surprising that the coefficient on durables is no longer significant. The coefficient on log per capita expenditure is significant at the 1 percent level, with a one standard deviation increase in expenditure leading to a 6 percentage point increase in the probability of child labor. In column (3) we add an indicator for landowning households. Landownership is related to wealth, but is also potentially correlated with the demand for child labor among agricultural households (see Bhalotra and Heady, 2003). The latter seems to dominate: landowning households are 20 percent more likely to use child labor. The coefficients on negative returns to education and per capita expenditure remain significant and similar in magnitude. Finally, the distance to primary and secondary school are both positively and significantly associated with child labor. A one-standard deviation ( 0.85 kilometer)

children. Rosenzweig and Wolpin (1985) examine the implications of experientially obtained knowledge for household structure and land markets. Picketty (1995) shows - albeit it in a very different setting - that 
increase in the distance to primary school leads to a 1.7 percentage point increase in the probability of child labor, and a one-standard deviation $(5 \mathrm{~km})$ increase in the distance to the nearest secondary school makes child labor 2.5 percentage points more likely.

Overall, our results in Table 12 suggest that behavioral factors - adults' own experience in the labor market - and landownership are the most important factors in accounting for child labor. But household wealth and the cost of sending children to school also play significant roles.

To the extent that these factors account for selection into child labor, we should control for them in our previous regressions. However, because our instrumental variables strategy is based on community rice prices and agricultural shocks, and because the variables we have examined in this section do not vary systematically with our instruments, our previous results remain valid. ${ }^{13}$

\section{Conclusion}

Much attention has been devoted recently to the problem of child labor. While the moral distaste for child labor is beyond question, we feel - particularly in developing countries where most child labor is rural and is a relatively low-intensity activity - that it is important to determine empirically whether child labor in fact has harmful consequences for children later in life. We view our work as a step in this direction.

We find that child labor significantly reduces school attainment. However, this negative effect is offset by increased earnings from wage and farm work among those who worked as children. Indeed, our results suggest that purely in terms of earnings, the 
loss from reduced education is more than fully offset by increased labor market experience as a child. We find no significant effects of child labor on health.

The conclusion we draw from these results is not that child labor is beneficial. Indeed, given the many qualifications and caveats to our results, we believe this would be inappropriate. Rather, we believe that our results show that in the medium run (i.e., over a five to ten-year horizon ) there are important economic benefits to child labor that offset its opportunity cost (lower school attainment) for households. However, over a longer horizon the returns to education increase, with more educated individuals experiencing increased wage growth, and the returns to work experience decrease. Thus, our findings provide a rationale for why child labor exists and illustrate the fundamental difficulty in reducing its prevalence.

Reducing child labor will require parents to be farsighted (i.e., to recognize the future returns to schooling) and to be able to engage in costly long-horizon investments (either through internal funding or borrowing). This conclusion underscores one of the key aspects of the ILO (2003) child labor report, namely that some kind of householdlevel transfers will be needed in order to lead to voluntary elimination of child labor.

\footnotetext{
${ }^{13}$ We confirm this by including the variables from this section as additional controls in our instrumental variables specifications; the results are unchanged.
} 


\section{REFERENCES}

Akabayashi, H., and Psacharopoulos, G. (1999). "The Trade-off Between Child Labor and Human Capital: A Tanzanian Case," Journal of Development Studies, 35 (5): 120140.

Alderman, H., J. Behrman, V. Lavy, and R. Menon (2001). "Child Health and School Enrollment: A Longitudinal Analysis," Journal of Human Resources, 26(1): 185-205.

Angrist, J. (1990). "Lifetime Earnings and the Vietnam Era Draft Lottery: Evidence from Social Security Administrative Records," American Economic Review, 80: 313-336.

Ashenfelter, O., and A.B. Krueger (1994). "Estimates of the Economic Return to Schooling from a New Sample of Twins," American Economic Review, 84: 1157-1173.

Ashenfelter, O. and C.E. Rouse (1998). "Income, Schooling, and Ability: Evidence from a New Sample of Twins," Quarterly Journal of Economics, 113: 253-284.

Basu, K. (1999). "Child Labor: Cause, Consequence, and Cure with Remarks on International Labor Standards," Journal of Economic Literature, 37: 1083-1119.

Beegle, K., R. Dehejia and R. Gatti (2003). "Child Labor, Crop Shocks and Credit Constraints," NBER Working Paper no.w10088.

Benjamin, D., and L. Brandt (2003). "Agriculture and Income Distribution in Rural Viet Nam under Economic Reforms: A Tale of Two Regions," in P. Glewwe, N. Agrawal and D. Dollar (eds), Economic Growth, Poverty and Household Welfare: Policy Lessons from Viet Nam. Washington DC: World Bank.

Bhalotra, S. and C. Heady (2003). "Child Farm Labour: The Wealth Paradox," World Bank Economic Review, 17: 197-227.

Boozer, M., and T. Suri (2001). "Child Labor and Schooling Decisions in Ghana," manuscript.

Cavalieri, C. (2002). "The Impact of Child Labor on Educational Performance: An Evaluation of Brazil," manuscript.

Edmonds, E. (2003). "Household Composition and the Response of Child Labor Supply to Product Market Integration: Evidence from Viet Nam," manuscript.

Edmonds, E., and N. Pavcnik (2003). "Product Market Integration and Household Labor Supply in a Poor Economy: Evidence from Viet Nam," manuscript. 
Edmonds, E., and C. Turk (2003). "Child Labor in Transition in Vietnam," in P. Glewwe, N. Agrawal, and D. Dollar (eds), Economic Growth, Poverty and Household Welfare: Policy Lessons from Viet Nam. Washington DC: World Bank.

Emerson, P., and A. Portela Souza (2002). "From Childhood to Adulthood: The Effect of Child Labor Activities on Adult Earnings in Brazil," manuscript, Latin American and Caribbean Economic Association Meetings 2002.

Glewwe, P. and H. Jacoby (1998). "School Enrollment and Completion in Vietnam: An Investigation of Recent Trends," in D. Dollar, P. Glewwe, and J. Litvack (eds), Household Welfare and Vietnam's Transition. Washington DC: World Bank.

Glewwe, P., H. Jacoby and E. King (2001). "Early Childhood Nutrition and Academic Achievement: A Longitudinal Analysis". Journal of Public Economics, 81: 345-368.

Heady, C. (2003). “The Effect of Child Labor on Learning Achievement," World Development, 31: 385-398.

Horowitz, Andrew, and Jian Wang (2004). "Favorite Son? Specialized Child Laborers and Students in Poor LDC Households," Journal of Development Economics, 73: 631642.

International Labour Organization (2002). A Future Without Child Labour. Geneva: International Labour Office.

International Labour Organization (2003). Investing in Every Child: An Economic Study of the Costs and Benefits of Eliminating Child Labour. Geneva: International Labour Office.

Jacoby, H. (1993). "Shadow Wages and Peasant Family Labor Supply: An Econometric Application to the Peruvian Sierra," The Review of Economic Studies, 60(4): 903-921

Jacoby, H. (1994). "Borrowing Constraints and Progress Through School: Evidence from Peru," The Review of Economics and Statistics, LXXVI: 151-160.

King, E., P. Orazem and E. Paterno. (1999). "Promotion With and Without Learning: Effects on Student Dropout," World Bank Working Paper Series on Impact Evaluation of Education Reforms, No. 18.

Kruger, D. (2002). "The Effect of Economic Opportunities on Child Work and Schooling," manuscript, Latin American and Caribbean Economic Association Meetings 2002.

Moock, P., H.A. Patrinos and M. Venkataraman (2003). "Education and Earnings in a Transition Economy: The Case of Vietnam," Economics of Education Review, 22(5). 
Morduch, J., "Poverty and Vulnerability," American Economic Review Papers and Proceedings, 84 (1994), 221-225.

O’Donnell O., E. Van Doorsaler and F. Rosati. (2003). "Health Effects of Children's Work: Evidence from Vietnam," forthcoming, Journal of Population Economics.

Patrinos, H. A., and G. Psacharopoulos (1995). "Educational Performance and Child Labor in Paraguay," International Journal of Educational Development, 15: 47-60.

Patrinos, H. A., and G. Psacharopoulos (1997). "Family Size, Schooling and Child Labor in Peru-An Empirical Analysis," Journal of Population Economics, 10: 387-405.

Psacharopoulos, G., and H. A. Patrinos (2002). "Returns to Investment in Education: A Further Update,” World Bank Working Paper Series, No. 2881.

Picketty, T. (1995). "Social Mobility and Redistributive Politics," Quarterly Journal of Economics, 60: 551-584.

Ravallion, M., and Q. Wodon (2000). "Does Child Labor Displace Schooling? Evidence on Behavioral Responses to an Enrollment Subsidy," The Economic Journal, 110: 158175.

Ray, D. (1998). Development Economics. Princeton: Princeton University Press.

Ray, R., and G. Lancaster (2003). "Does Child Labour Affect School Attendance and School Performance? Multi Country Evidence on SIMPOC Data," manuscript.

Rosati, F. and Z. Tzannatos (2004). "Child Labor in Vietnam," forthcoming, Pacific Economic Review.

Rosenzweig, M. and K. Wolpin (1985). "Specific Experience, Household Structure and Intergenerational Transfers: Farm Family Land and Labor Arrangements in Developing Countries," Quarterly Journal of Economics, 100: 961-987.

Strauss, J. and D. Thomas (1995). "Human Resources: Empirical Modeling of Household and Family Decisions," in J. Behrman and T.N. Srinivasan (eds), Handbook of Development Economics, vol. 3A. Amsterdam: North-Holland.

Zeldes, S. (1989). "Consumption and Liquidity Constraints: An Empirical Investigation," Journal of Political Economy, XCVII: 305-346. 
Table 1: Descriptive Statistics

\begin{tabular}{|c|c|c|c|}
\hline & $\begin{array}{c}\text { Full sample } \\
\text { (children 8-13 in 1992-93) }\end{array}$ & $\begin{array}{c}\text { Children not } \\
\text { working in 1992-93 } \\
\end{array}$ & $\begin{array}{c}\text { Children working } \\
\text { in 1992-93 } \\
\end{array}$ \\
\hline Labor hours (wage + non-wage) in the last & 7.13 & & 23.75 \\
\hline 7 days, 1992-93 & $(12.67)$ & & $(11.83)$ \\
\hline \multirow[t]{2}{*}{ Age, 1992-93 } & 10.16 & 9.92 & 10.71 \\
\hline & $(1.61)$ & $(1.57)$ & $(1.57)$ \\
\hline \multirow[t]{2}{*}{ Male $^{(a)}$} & 0.53 & 0.52 & 0.53 \\
\hline & $(0.50)$ & $(0.50)$ & $(0.50)$ \\
\hline \multirow[t]{2}{*}{ Father's education } & 7.07 & 6.90 & 7.46 \\
\hline & $(3.81)$ & $(3.91)$ & (3.54) \\
\hline \multirow[t]{2}{*}{ Mother's education } & 5.46 & 5.28 & 5.90 \\
\hline & $(3.49)$ & $(3.52)$ & $(3.39)$ \\
\hline \multirow[t]{2}{*}{ log per capita expenditure, 1992-93 } & 7.32 & 7.36 & 7.22 \\
\hline & $(0.44)$ & $(0.44)$ & $(0.41)$ \\
\hline \multirow[t]{2}{*}{ Rice price 1992-93 (/1000) } & 1.76 & 1.75 & 1.78 \\
\hline & $(0.24)$ & $(0.22)$ & $(0.28)$ \\
\hline Community disaster & 0.77 & 0.78 & 0.76 \\
\hline in last 12 months $1992-93^{(\mathrm{a})}$ & $(0.42)$ & $(0.41)$ & $(0.43)$ \\
\hline \multirow[t]{2}{*}{ In school, 1997-98 ${ }^{(\mathrm{a})}$} & 0.63 & 0.65 & 0.57 \\
\hline & $(0.48)$ & $(0.48)$ & $(0.49)$ \\
\hline \multirow[t]{2}{*}{ Highest grade attained, 1997-98 } & 7.57 & 7.40 & 7.95 \\
\hline & $(2.29)$ & $(2.28)$ & $(2.28)$ \\
\hline \multirow[t]{2}{*}{ Wage worker in last 7 days, $1997-98^{(a)}$} & 0.06 & 0.06 & 0.06 \\
\hline & $(0.24)$ & $(0.23)$ & $(0.25)$ \\
\hline \multirow[t]{2}{*}{ Market earnings per day, 1997-98 } & 0.88 & 0.87 & 0.88 \\
\hline & $(4.15)$ & $(4.11)$ & $(4.25)$ \\
\hline \multirow[t]{2}{*}{ Wage per day, 1997-1998 } & 4.08 & 4.37 & 3.45 \\
\hline & $(5.96)$ & $(6.22)$ & $(5.33)$ \\
\hline \multirow[t]{2}{*}{ Any illness in last 4 weeks, $1998^{(\mathrm{a})}$} & 0.28 & 0.28 & 0.28 \\
\hline & $(0.45)$ & $(0.45)$ & $(0.45)$ \\
\hline \multirow[t]{2}{*}{ Number of days ill in last 4 weeks, 1998} & 1.58 & 1.47 & 1.83 \\
\hline & $(3.80)$ & $(3.55)$ & $(4.31)$ \\
\hline \multirow[t]{2}{*}{ BMI, 1998} & 17.83 & 17.70 & 18.12 \\
\hline & $(1.96)$ & $(1.99)$ & $(1.87)$ \\
\hline Number of observations & 2,133 & 1,493 & 640 \\
\hline
\end{tabular}

Notes: Number of observations for estimated wage 1,861, 1,263, and 598. Number of observations for BMI = 1,974, 1,376, and 598. (a) This is a binary variable, equal to 1 if true, else equal to 0 . 
Table 2: Outcomes in 1997-98, conditional on being in school in 1992-93: OLS

\begin{tabular}{|c|c|c|c|c|c|}
\hline Dependent variable: & $\begin{array}{c}(1) \\
\text { In school }\end{array}$ & $\begin{array}{c}(2) \\
\text { Highest grade } \\
\text { attained }\end{array}$ & $\begin{array}{c}(3) \\
\text { Wage worker } \\
\text { in last } 7 \text { days }\end{array}$ & $\begin{array}{c}(4) \\
\text { Market } \\
\text { earnings per } \\
\text { day } \\
\end{array}$ & $\begin{array}{c}(5) \\
\text { Wage per } \\
\text { day }^{(a)}\end{array}$ \\
\hline Labor hours 1992-93 & $\begin{array}{l}-0.001 \\
(0.001)\end{array}$ & $\begin{array}{c}0.005 \\
(0.004)\end{array}$ & $\begin{array}{c}0.001 * \\
(0.001)\end{array}$ & $\begin{array}{c}0.014 \\
(0.009)\end{array}$ & $\begin{array}{c}0.004 \\
(0.011)\end{array}$ \\
\hline Male & $\begin{array}{l}0.094 * * * \\
(0.018)\end{array}$ & $\begin{array}{c}0.015 \\
(0.082)\end{array}$ & $\begin{array}{l}-0.004 \\
(0.010)\end{array}$ & $\begin{array}{c}0.044 \\
(0.176)\end{array}$ & $\begin{array}{l}3.064 * * * \\
(0.253)\end{array}$ \\
\hline Father's education & $\begin{array}{l}0.011 * * * \\
(0.003)\end{array}$ & $\begin{array}{l}0.116^{* * * *} \\
(0.014)\end{array}$ & $\begin{array}{l}-0.004 * * \\
(0.002)\end{array}$ & $\begin{array}{l}-0.064 * * \\
(0.027)\end{array}$ & $\begin{array}{l}-0.016 \\
(0.043)\end{array}$ \\
\hline Mother's education & $\begin{array}{l}0.021 * * * \\
(0.003)\end{array}$ & $\begin{array}{l}0.141 * * * \\
(0.015)\end{array}$ & $\begin{array}{c}0.001 \\
(0.002)\end{array}$ & $\begin{array}{c}0.011 \\
(0.028)\end{array}$ & $\begin{array}{c}0.053 \\
(0.041)\end{array}$ \\
\hline LN Per Cap Exp. 1992-93 & $\begin{array}{l}0.121 * * * \\
(0.024)\end{array}$ & $\begin{array}{l}0.841 * * * \\
(0.111)\end{array}$ & $\begin{array}{c}-0.032 * * * \\
(0.012)\end{array}$ & $\begin{array}{l}-0.424 * \\
(0.222)\end{array}$ & $\begin{array}{c}0.248 \\
(0.333)\end{array}$ \\
\hline R-squared & 0.24 & 0.33 & 0.05 & 0.05 & 0.17 \\
\hline Number of observations & 2,133 & 2,133 & 2,133 & 2,133 & 1,861 \\
\hline
\end{tabular}

Notes: Standard errors are in parentheses and are clustered at the community level. $* * *$ indicates significance at $1 \%$; $*$ at $5 \%$; and, $*$ at $10 \%$. Other regressors included, but omitted from the table, are age and indicator variables for missing parental education and region. (a) Wages per day is market wage when it is available; otherwise it is estimated farm wages. 
Table 3: First Stage Estimates, Dependent variable: Labor Hours in 1992-93

\begin{tabular}{|c|c|c|c|}
\hline & $(1)$ & $(2)$ & (3) \\
\hline \multirow[t]{2}{*}{ Rice price $1992-93$} & $-4.67 * * *$ & $-4.81 * * *$ & $-4.21 * * *$ \\
\hline & $(1.18)$ & $(1.19)$ & $(1.21)$ \\
\hline \multirow[t]{2}{*}{ Community disaster $1992-93^{(a)}$} & $29.11^{* * *}$ & $29.60 * * *$ & $28.67 * * *$ \\
\hline & $(9.27)$ & $(9.32)$ & $(9.37)$ \\
\hline Community disaster $\mathrm{x}$ & $-3.82 * * *$ & $-3.89 * * *$ & $-3.81 * * *$ \\
\hline LN Per Cap Exp. 1992-93 & $(1.24)$ & $(1.25)$ & $(1.26)$ \\
\hline \multirow[t]{2}{*}{ Male } & -0.09 & -0.08 & -0.11 \\
\hline & $(0.50)$ & $(0.50)$ & $(0.50)$ \\
\hline \multirow[t]{2}{*}{ Father's education } & $-0.17 *$ & $-0.17 *$ & $-0.19 * *$ \\
\hline & $(0.09)$ & $(0.09)$ & $(0.09)$ \\
\hline \multirow[t]{2}{*}{ Mother's education } & -0.10 & -0.11 & -0.16 \\
\hline & $(0.10)$ & $(0.10)$ & $(0.10)$ \\
\hline \multirow[t]{2}{*}{ LN Per Cap Exp. 1992-93 } & 1.60 & 1.65 & 1.81 \\
\hline & $(1.10)$ & $(1.10)$ & $(1.11)$ \\
\hline \multirow[t]{2}{*}{ Rice price $1997-98$} & & 0.46 & 0.00 \\
\hline & & $(0.61)$ & $(0.63)$ \\
\hline \multirow[t]{2}{*}{ Population (/1000) } & & & $-0.11 * *$ \\
\hline & & & $(0.05)$ \\
\hline \multirow[t]{2}{*}{ Road passing by } & & & $2.65 * * *$ \\
\hline & & & $(0.88)$ \\
\hline \multirow[t]{2}{*}{ Village electrified } & & & -0.61 \\
\hline & & & $(0.96)$ \\
\hline \multirow[t]{2}{*}{ Number of tractors } & & & -0.02 \\
\hline & & & $(0.02)$ \\
\hline F-test on instruments & 9.07 & 9.23 & 8.57 \\
\hline Number of observations & 2,133 & 2,133 & 2,082 \\
\hline
\end{tabular}


Table 4: Robustness of the Instruments: Outcomes in 1997-98

\begin{tabular}{lcccccc}
\hline \hline \multicolumn{1}{c}{ Dependent variable: } & $\begin{array}{c}(1) \\
\text { Community } \\
\text { disaster } \\
1997-98\end{array}$ & $\begin{array}{c}(2) \\
\text { Upper } \\
\text { secondary } \\
\text { school in village } \\
1997-98\end{array}$ & $\begin{array}{c}\text { Log (Value of } \\
\text { durable assets) } \\
1997-98\end{array}$ & $\begin{array}{c}\text { (4) in the } \\
\text { last month } \\
1992-93\end{array}$ & $\begin{array}{c}\text { Ill in the last } \\
12 \text { months } \\
1992-93\end{array}$ & $\begin{array}{c}\text { Growth in log (per } \\
\text { capita } \\
\text { expenditure) } \\
1992 / 93-1997 / 98\end{array}$ \\
\hline Rice price 1992-93 & 0.030 & 0.028 & -0.092 & -0.070 & -0.057 & 0.026 \\
Community disaster 1992-93 & $(0.105)$ & $(0.148)$ & $(0.205)$ & $(0.053)$ & $(0.067)$ & $(0.061)$ \\
& -0.010 & -0.072 & 1.955 & 0.501 & -0.020 & 0.617 \\
Community disaster x & $(0.056)$ & $(0.089)$ & $(1.689)$ & $(0.341)$ & $(0.446)$ & $(0.512)$ \\
LN Per Cap Exp. 1992-93 & & & -0.263 & -0.070 & 0.003 & -0.086 \\
Number of observations & & & $(0.223)$ & $(0.047)$ & $(0.060)$ & $(0.070)$ \\
Regression is run at level of & Community & Community & Household & Individual & Individual & Household \\
\hline
\end{tabular}

Notes: OLS estimates. Standard errors are in parentheses and are clustered at the community level. *** indicates significance at $1 \% ; * *$ at $5 \%$; and, $*$ at $10 \%$. Other regressors included, but omitted from the table, are: region fixed effects, LN per capita expenditure (columns 3-6), and age, parental education, indicator variables for missing parental education, gender (columns 4-5). 
Table 5: Robustness of the Instruments: In School in 1997-98

\begin{tabular}{|c|c|c|c|c|}
\hline $\begin{array}{l}\text { Specification: } \\
\text { Instrument set: }\end{array}$ & $\begin{array}{c}(1) \\
\text { IV } \\
\text { Rice price, } \\
\text { community } \\
\text { disaster, } \\
\text { interaction } \\
\end{array}$ & $\begin{array}{c}(2) \\
\text { IV } \\
\text { Rice price }\end{array}$ & $\begin{array}{c}\text { (3) } \\
\text { IV } \\
\text { Community } \\
\text { disaster }\end{array}$ & $\begin{array}{c}\text { (4) } \\
\text { IV } \\
\text { Rice price, } \\
\text { community } \\
\text { disaster }\end{array}$ \\
\hline Labor hours 1992-93 & $\begin{array}{l}-0.025^{* * * *} \\
(0.008)\end{array}$ & $\begin{array}{l}-0.029 * * \\
(0.012)\end{array}$ & $\begin{array}{l}-0.206 \\
(0.441)\end{array}$ & $\begin{array}{l}-0.036^{* * * *} \\
(0.012)\end{array}$ \\
\hline Male & $\begin{array}{l}0.092 * * * \\
(0.022)\end{array}$ & $\begin{array}{l}0.092 * * * \\
(0.023)\end{array}$ & $\begin{array}{c}0.078 \\
(0.110)\end{array}$ & $\begin{array}{l}0.091 * * * \\
(0.025)\end{array}$ \\
\hline Father's education & $\begin{array}{c}0.007 * \\
(0.004)\end{array}$ & $\begin{array}{c}0.006 \\
(0.004)\end{array}$ & $\begin{array}{l}-0.022 \\
(0.074)\end{array}$ & $\begin{array}{c}0.005 \\
(0.005)\end{array}$ \\
\hline Mother's education & $\begin{array}{l}0.018 * * * \\
(0.004)\end{array}$ & $\begin{array}{l}0.018 * * * \\
(0.005)\end{array}$ & $\begin{array}{l}-0.002 \\
(0.053)\end{array}$ & $\begin{array}{l}0.017 * * * \\
(0.005)\end{array}$ \\
\hline LN Per Cap Exp. 1992-93 & $\begin{array}{l}0.090 * * * \\
(0.030)\end{array}$ & $\begin{array}{l}0.085^{* *} \\
(0.033)\end{array}$ & $\begin{array}{l}-0.141 \\
(0.578)\end{array}$ & $\begin{array}{l}0.075^{* *} \\
(0.036)\end{array}$ \\
\hline P-value of OIR test & 0.24 & -- & -- & 0.29 \\
\hline Number of observations & 2,133 & 2,133 & 2,133 & 2,133 \\
\hline
\end{tabular}

Notes: Standard errors are in parentheses and are clustered at the community level. *** indicates significance at $1 \%$; ** at $5 \%$; and, * at $10 \%$. Other regressors included, but omitted from the table, are age and indicator variables for missing parental education and region fixed effects. 
Table 6: Outcomes in 1997-98, conditional on being in school in 1992-93: IV

\begin{tabular}{|c|c|c|c|c|c|c|}
\hline Dependent variable: & $\begin{array}{c}(1) \\
\text { In school }\end{array}$ & $\begin{array}{c}(2) \\
\text { Highest grade } \\
\text { attained }\end{array}$ & $\begin{array}{c}(3) \\
\text { Wage worker } \\
\text { in last } 7 \text { days }\end{array}$ & $\begin{array}{c}(4) \\
\text { Market } \\
\text { earnings per } \\
\text { day }\end{array}$ & $\begin{array}{c}(5) \\
\text { Market } \\
\text { earnings per } \\
\text { day, ages 17- } \\
19 \text { in 1997-98 }\end{array}$ & $\begin{array}{c}(6) \\
\text { Wage per } \\
\text { day }^{(\text {a) }}\end{array}$ \\
\hline \multirow[t]{2}{*}{ Labor hours 1992-93 } & $-0.025 * * *$ & $-0.062 *$ & $0.005^{*}$ & $0.118^{*}$ & $0.219 *$ & $0.226 * * *$ \\
\hline & $(0.008)$ & $(0.034)$ & $(0.003)$ & $(0.064)$ & $(0.127)$ & $(0.085)$ \\
\hline \multirow[t]{2}{*}{ Male } & $0.092 * * *$ & 0.009 & -0.004 & 0.053 & 0.147 & $3.047 * * *$ \\
\hline & $(0.022)$ & $(0.088)$ & $(0.010)$ & $(0.182)$ & $(0.525)$ & $(0.279)$ \\
\hline \multirow[t]{2}{*}{ Father's education } & $0.007 *$ & $0.105^{* * *}$ & $-0.003 *$ & -0.048 & -0.078 & 0.006 \\
\hline & $(0.004)$ & $(0.016)$ & $(0.002)$ & $(0.030)$ & $(0.089)$ & $(0.049)$ \\
\hline \multirow[t]{2}{*}{ Mother's education } & $0.018 * * *$ & $0.133 * * *$ & 0.001 & 0.023 & -0.006 & 0.082 \\
\hline & $(0.004)$ & $(0.017)$ & $(0.002)$ & $(0.031)$ & $(0.095)$ & $(0.051)$ \\
\hline \multirow[t]{2}{*}{ LN Per Cap Exp. 1992-93 } & $0.090 * * *$ & $0.756 * * *$ & $-0.026^{* *}$ & -0.291 & 0.856 & 0.562 \\
\hline & $(0.030)$ & $(0.127)$ & $(0.013)$ & $(0.253)$ & $(0.870)$ & $(0.390)$ \\
\hline$\%$ effect at mean of work hours & $28 \%$ & $6 \%$ & $60 \%$ & $96 \%$ & $91 \%$ & $40 \%$ \\
\hline Number of observations & 2,133 & 2,133 & 2,133 & 2,133 & 528 & 1,861 \\
\hline
\end{tabular}

Notes: Standard errors are in parentheses and are clustered at the community level. *** indicates significance at 1\%; ** at 5\%; and, * at $10 \%$. Other regressors included, but omitted from the table, are age and indicator variables for missing parental education and region fixed effects. (a) Wages per day is market wage when it is available; otherwise it is estimated farm wages. 
Table 7: Heterogeneous Treatment Effect of Child Labor on Outcomes

\begin{tabular}{|c|c|c|c|c|c|}
\hline Dependent variable: & $\begin{array}{c}(1) \\
\text { In school }\end{array}$ & $\begin{array}{c}\text { (2) } \\
\text { Highest grade } \\
\text { attained }\end{array}$ & $\begin{array}{c}\text { (3) } \\
\text { Wage worker } \\
\text { in last } 7 \text { days }\end{array}$ & $\begin{array}{c}(4) \\
\text { Market } \\
\text { earnings per } \\
\text { day } \\
\end{array}$ & $\begin{array}{c}(5) \\
\text { Wage per } \\
\text { day }^{(a)}\end{array}$ \\
\hline Worked more than median & -0.470 & -3.507 & 0.214 & 5.043 & $11.336^{*}$ \\
\hline (0 hours per week) & $(0.419)$ & $(2.245)$ & $(0.214)$ & $(4.303)$ & $(6.388)$ \\
\hline Worked more than $75^{\text {th }}$ & $-0.924 * *$ & $-2.770^{*}$ & 0.133 & 3.423 & $8.113 * *$ \\
\hline percentile ( 12 hours per week) & $(0.409)$ & $(1.645)$ & $(0.163)$ & $(3.086)$ & $(4.016)$ \\
\hline Worked more than $90^{\text {th }}$ & $-1.073^{* * *}$ & $-2.119^{*}$ & $0.202 * *$ & $4.394^{* *}$ & $8.477 * * *$ \\
\hline percentile ( 28 hours per week) & $(0.304)$ & $(1.190)$ & $(0.126)$ & (2.198) & $(3.021)$ \\
\hline
\end{tabular}

Notes: Each cell represents a separate regression of the outcome identified in the column on the treatment and subsample as defined in each row. Each regression also controls for age, mother's education, father's education, region fixed effects, and instruments for child labor using rice prices and community shocks. Standard errors are in parentheses and are clustered at the community level. $* * *$ indicates significance at $1 \%$; ** at $5 \%$; and, * at $10 \%$. Results are robust to controlling for availability of schools and roads at the village level. The magnitudes of the estimates are similar, though we lose precision in some cases. (a) Wages per day is market wage when it is available; otherwise it is estimated farm wages. 
Table 8: Outcomes in 1997-98, conditional on being in school in 1992-93: IV with Rice Price Controls

\begin{tabular}{|c|c|c|c|c|c|c|c|c|}
\hline Dependent variable: & $\begin{array}{c}(1) \\
\text { Wage per } \\
\text { day / rice } \\
\text { price }\end{array}$ & $\begin{array}{c}\text { (2) } \\
\text { Adult } \\
\text { wage per } \\
\text { day }^{(a)}\end{array}$ & $\begin{array}{l}\text { (3) } \\
\text { Highest grade } \\
\text { attained, } \\
\text { Northern VN }\end{array}$ & $\begin{array}{c}\text { (4) } \\
\text { Market } \\
\text { earnings per } \\
\text { day, North- } \\
\text { ern VN } \\
\end{array}$ & $\begin{array}{c}\text { (5) } \\
\text { Wage per } \\
\text { day, North- } \\
\text { ern } \mathrm{VN}^{(\mathrm{b})}\end{array}$ & $\begin{array}{c}(6) \\
\text { Highest } \\
\text { grade } \\
\text { attained }\end{array}$ & $\begin{array}{c}\text { (7) } \\
\text { Market } \\
\text { earnings } \\
\text { per day }\end{array}$ & $\begin{array}{c}(8) \\
\text { Wage per } \\
\text { day }^{(b)}\end{array}$ \\
\hline Labor hours 1992-93 & $\begin{array}{l}0.084 * * * \\
(0.027)\end{array}$ & $\begin{array}{l}-0.010 \\
(0.094)\end{array}$ & $\begin{array}{l}-0.062^{* *} \\
(0.032)\end{array}$ & $\begin{array}{c}0.101^{*} \\
(0.065)\end{array}$ & $\begin{array}{c}0.141 * \\
(0.077)\end{array}$ & $\begin{array}{l}-0.061 * \\
(0.038)\end{array}$ & $\begin{array}{l}0.121 * \\
(0.07)\end{array}$ & $\begin{array}{l}0.256 * * * \\
(0.096)\end{array}$ \\
\hline Male & $\begin{array}{l}0.892 * * * \\
(0.086)\end{array}$ & $\begin{array}{l}4.307 * * * \\
(0.465)\end{array}$ & $\begin{array}{c}0.021 \\
(0.112)\end{array}$ & $\begin{array}{c}0.015 \\
(0.169)\end{array}$ & $\begin{array}{l}2.492 * * * \\
(0.307)\end{array}$ & $\begin{array}{c}0.018 \\
(0.089)\end{array}$ & $\begin{array}{c}0.053 \\
(0.187)\end{array}$ & $\begin{array}{l}3.047 * * * \\
(0.294)\end{array}$ \\
\hline Father's education & $\begin{array}{c}0.004 \\
(0.015)\end{array}$ & $\begin{array}{c}0.074 \\
(0.053)\end{array}$ & $\begin{array}{l}0.081 * * * \\
(0.019)\end{array}$ & $\begin{array}{l}-0.020 \\
(0.028)\end{array}$ & $\begin{array}{c}0.007 \\
(0.054)\end{array}$ & $\begin{array}{l}0.103 * * * \\
(0.016)\end{array}$ & $\begin{array}{l}-0.043 \\
(0.031)\end{array}$ & $\begin{array}{c}0.015 \\
(0.051)\end{array}$ \\
\hline Mother's education & $\begin{array}{c}0.021 \\
(0.016)\end{array}$ & $\begin{array}{c}0.161 * \\
(0.094)\end{array}$ & $\begin{array}{l}0.106^{* * * *} \\
(0.021)\end{array}$ & $\begin{array}{c}0.037 \\
(0.032)\end{array}$ & $\begin{array}{c}0.045 \\
(0.045)\end{array}$ & $\begin{array}{l}0.127 * * * \\
(0.018)\end{array}$ & $\begin{array}{c}0.022 \\
(0.035)\end{array}$ & $\begin{array}{c}0.098 * \\
(0.057)\end{array}$ \\
\hline LN Per Cap Exp. 1992-93 & $\begin{array}{c}0.195 * \\
(0.118)\end{array}$ & $\begin{array}{l}1.249 * * * \\
(0.297)\end{array}$ & $\begin{array}{l}0.774 * * * \\
(0.178)\end{array}$ & $\begin{array}{c}0.521 \\
(0.413)\end{array}$ & $\begin{array}{l}1.559 * * * \\
(0.551)\end{array}$ & $\begin{array}{l}0.750 * * * \\
(0.125)\end{array}$ & $\begin{array}{l}-0.368 \\
(0.257)\end{array}$ & $\begin{array}{c}0.505 \\
(0.395)\end{array}$ \\
\hline \multicolumn{9}{|l|}{ Community characteristics 1992-93 } \\
\hline Population (/1000) & & & & & & $\begin{array}{c}0.001 \\
(0.011)\end{array}$ & $\begin{array}{c}0.043 * \\
(0.025)\end{array}$ & $\begin{array}{c}0.020 \\
(0.037)\end{array}$ \\
\hline Road passing by (c) & & & & & & $\begin{array}{l}0.444 * * \\
(0.205)\end{array}$ & $\begin{array}{c}0.133 \\
(0.454)\end{array}$ & $\begin{array}{c}0.033 \\
(0.620)\end{array}$ \\
\hline Village electrified (c) & & & & & & $\begin{array}{c}0.092 \\
(0.144)\end{array}$ & $\begin{array}{l}-0.289 \\
(0.349)\end{array}$ & $\begin{array}{l}-0.535 \\
(0.497)\end{array}$ \\
\hline Number of tractors & & & & & & $\begin{array}{l}-0.005 \\
(0.004)\end{array}$ & $\begin{array}{l}-0.015^{* *} \\
(0.006)\end{array}$ & $\begin{array}{l}-0.010 \\
(0.010)\end{array}$ \\
\hline Rice price $1997-98$ & & & & & & $\begin{array}{l}0.383 * * * \\
(0.107)\end{array}$ & $\begin{array}{c}0.035 \\
(0.231)\end{array}$ & $\begin{array}{c}0.377 \\
(0.358)\end{array}$ \\
\hline Number of observations & 1,861 & 6,154 & 1,125 & 1,125 & 1,036 & 2,082 & 2,082 & 1,817 \\
\hline
\end{tabular}

Notes: Standard errors are in parentheses and are clustered at the community level. *** indicates significance at $1 \%$; ** at 5\%; and, * at $10 \%$. Other regressors included, but omitted from the table, are age and indicator variables for missing parental education and tractors, and region fixed effects. Results are robust to controlling for availability of schools and roads at the village level. (a) Own labor hours from the sample of adults are used as regressors. (b) Wages per day is market wage when it is available; otherwise it is estimated farm wages. (c) This is a binary variable, equal to 1 if true, else equal to 0. 
Table 9: Outcomes in 1997-98, conditional on being in school in 1992-93: Household Fixed Effects

\begin{tabular}{|c|c|c|c|c|c|}
\hline Dependent variable: & $\begin{array}{c}(1) \\
\text { In school }\end{array}$ & $\begin{array}{c}(2) \\
\text { Highest } \\
\text { grade } \\
\text { attained }\end{array}$ & $\begin{array}{c}(3) \\
\text { Wage } \\
\text { worker }\end{array}$ & $\begin{array}{c}\text { (4) } \\
\text { Market } \\
\text { earnings per } \\
\text { day }\end{array}$ & $\begin{array}{c}(5) \\
\text { Wage per } \\
\text { day }^{(a)}\end{array}$ \\
\hline \multirow[t]{2}{*}{ Labor hours 1992-93 } & $-0.004 * * *$ & -0.004 & $0.001 *$ & $0.028 * *$ & $0.026 *$ \\
\hline & $(0.001)$ & $(0.005)$ & $(0.0012)$ & $(0.012)$ & $(0.016)$ \\
\hline \multirow[t]{2}{*}{ Male } & $0.109 * * *$ & 0.111 & 0.006 & 0.065 & $3.53 * * *$ \\
\hline & $(0.027)$ & $(1.01)$ & $(0.44)$ & $(0.229)$ & $(0.32)$ \\
\hline Number of observations & 2,133 & 2,133 & 2,133 & 2,133 & 1,861 \\
\hline
\end{tabular}


Table 10: Health Outcomes in 1997-98, conditional on being in school in 1992-93

\begin{tabular}{lccc}
\hline \hline & $(1)$ & $(2)$ & $(3)$ \\
Dependent variable: & Any illness & Days ill if ill & Growth \\
\hline Labor hours 1992-93 & 0.012 & 0.318 & 0.145 \\
& $(0.008)$ & $(0.312)$ & $(0.141)$ \\
Number of observations & 2,133 & 603 & 1,974 \\
\hline
\end{tabular}

Notes: Labor hours are predicted using instrumental variables. Standard errors are in parentheses and are clustered at the community level. *** indicates significance at $1 \%$; $* *$ at $5 \%$; and, * at $10 \%$. Other regressors included, but omitted from the table, are age, gender, and indicator variables for missing parental education and region fixed effects. In column 3, growth is measured as the change in natural logarithm of body mass index (BMI) controlling for lagged value of BMI. 
Table 11: Returns to Education and Experience Among Adults in 1997-98

\begin{tabular}{|c|c|c|c|c|}
\hline Dependent variable: & $\begin{array}{c}(1) \\
\text { Market earnings } \\
\text { per day }\end{array}$ & $\begin{array}{c}(2) \\
\text { Wage per day }{ }^{(a)}\end{array}$ & $\begin{array}{c}(3) \\
\text { Market earnings } \\
\text { per day }\end{array}$ & $\begin{array}{c}(4) \\
\text { Wages per day }^{(a)}\end{array}$ \\
\hline \multirow[t]{2}{*}{ Education } & $-0.881 * * *$ & $-0.548 * * *$ & $-0.739 * * *$ & -0.276 \\
\hline & $(0.128)$ & $(0.165)$ & $(0.168)$ & $(0.202)$ \\
\hline \multirow[t]{2}{*}{ Education $\cdot$ Age } & $0.051 * * *$ & $0.039 * * *$ & $0.047 * * *$ & $0.027 * * *$ \\
\hline & $(0.006)$ & $(0.008)$ & $(0.008)$ & $(0.010)$ \\
\hline \multirow[t]{2}{*}{ Education $\cdot \operatorname{Age}^{2}(/ 1000)$} & $-0.530 * * *$ & $-0.382 * * *$ & $-0.520 * * *$ & $-0.258 * *$ \\
\hline & $(0.057)$ & $(0.082)$ & $(0.093)$ & $(0.114)$ \\
\hline \multirow[t]{2}{*}{ Age } & $-0.323 * * *$ & $-0.324 * * *$ & $-0.301 * * *$ & $-0.306^{* * *}$ \\
\hline & $(0.037)$ & $(0.047)$ & $(0.047)$ & $(0.057)$ \\
\hline \multirow[t]{2}{*}{$\operatorname{Age}^{2}(/ 100)$} & $0.260 * * *$ & $0.273 * * *$ & $0.250 * * *$ & $0.280^{* * *}$ \\
\hline & $(0.033)$ & $(0.045)$ & $(0.048)$ & $(0.058)$ \\
\hline Household fixed effects & No & No & Yes & Yes \\
\hline Number of observations & 9,545 & 8,358 & 9,545 & 8,358 \\
\hline
\end{tabular}


Table 12: Probability of Child Labor in the Household in 1992-93: Impact of Adult Characteristics

\begin{tabular}{lccccc}
\hline \hline & $(1)$ & $(2)$ & $(3)$ & $(4)$ & $(5)$ \\
\hline Returns to education $_{\text {negative }}^{*}$ & $0.054^{*}$ & $0.060^{* *}$ & $0.067^{* *}$ & $0.067^{* *}$ & $0.069^{* *}$ \\
Household size & $(0.030)$ & $(0.031)$ & $(0.031)$ & $(0.031)$ & $(0.031)$ \\
& $0.014^{* *}$ & 0.01 & 0.011 & 0.01 & 0.010 \\
LN Per Cap Durable Goods & $(0.007)$ & $(0.007)$ & $(0.007)$ & $(0.007)$ & $(0.007)$ \\
& $-0.040^{* * *}$ & -0.013 & -0.013 & -0.012 & -0.010 \\
LN Per Cap Expenditure & $(0.009)$ & $(0.012)$ & $(0.012)$ & $(0.012)$ & $(0.012)$ \\
& & $-0.139^{* * *}$ & $-0.132^{* * *}$ & $-0.132^{* * *}$ & $-0.124^{* * *}$ \\
Household owns land & & $(0.038)$ & $(0.040)$ & $(0.040)$ & $(0.040)$ \\
& & & $0.212^{* * *}$ & $0.215^{* * *}$ & $0.217^{* * * *}$ \\
Distance to primary school & & & $(0.060)$ & $(0.060)$ & $(0.060)$ \\
attended (kms) & & & & $0.025^{*}$ & 0.020 \\
Distance to secondary & & & & $(0.015)$ & $(0.015)$ \\
school nearest community (kms) & & & & & $0.007 * * *$ \\
& & & & & $(0.003)$ \\
Observations & 1,550 & 1,550 & 1,491 & 1,491 & 1,491 \\
\hline
\end{tabular}

Notes: Probit estimates for households with children between the ages of 8 and 13 in 1992-93. Marginal coefficients are reported. Standard errors are in parentheses. $* * *$ indicates significance at $1 \%$; ** at 5\%; and, * at $10 \%$.

* This variable is an indicator for households in which no adult had estimated positive returns to education in 1993 . Individual returns to education are estimated using the sample of adults over 17 years by regressing earnings per day on completed education, age, age interacted with education, and region fixed effects. (a) This is a binary variable, equal to 1 if true, else equal to 0. 
Figure 1: Age Profile of the Education and Experience Effects for Market Earnings per Day

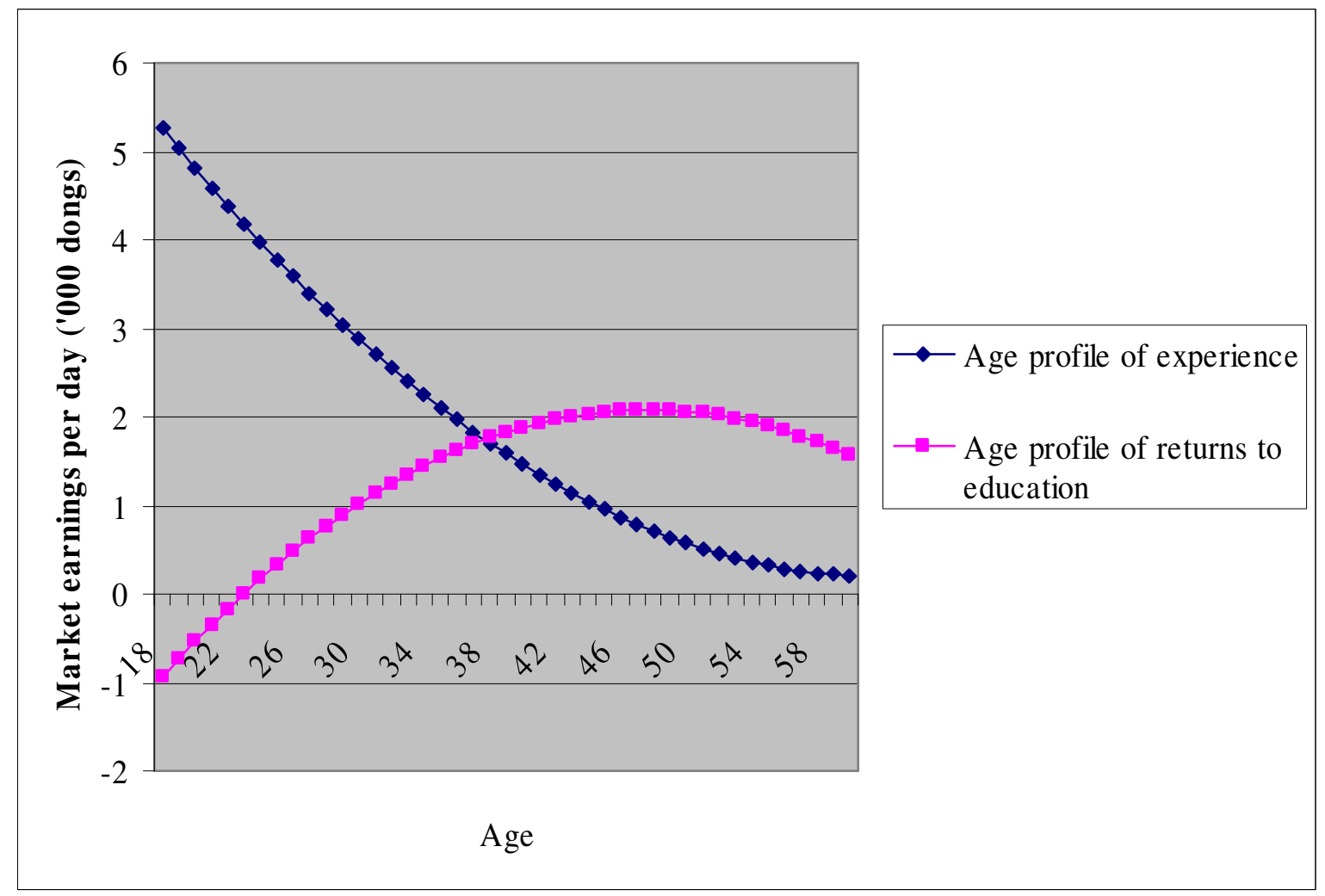

Notes: The line for experience plots the education, education.age, and education $\cdot a^{2} e^{2}$ terms from column (1) of Table 11 . The line for the age effect plots the constant, age, and age ${ }^{2}$ terms. 
Figure 2: Age Profile of the Education and Experience Effects for Wages per Day

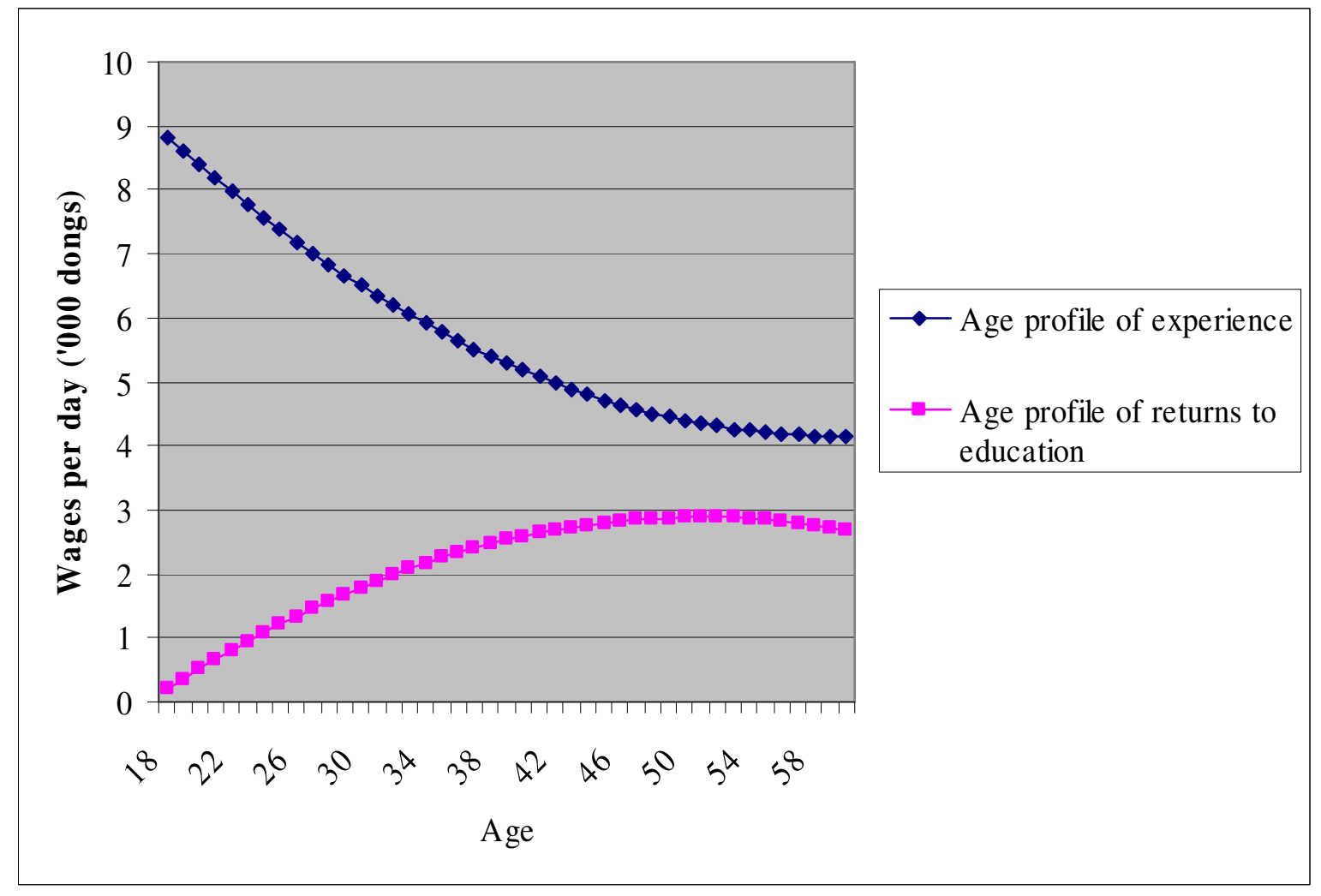

Notes: The line for experience plots the education, education·age, and education age $^{2}$ terms from column (2) of Table 11. The line for the age effect plots the constant, age, and age ${ }^{2}$ terms. 
Figure 3: Comparing Profiles of Wages per Day with and without Child Labor

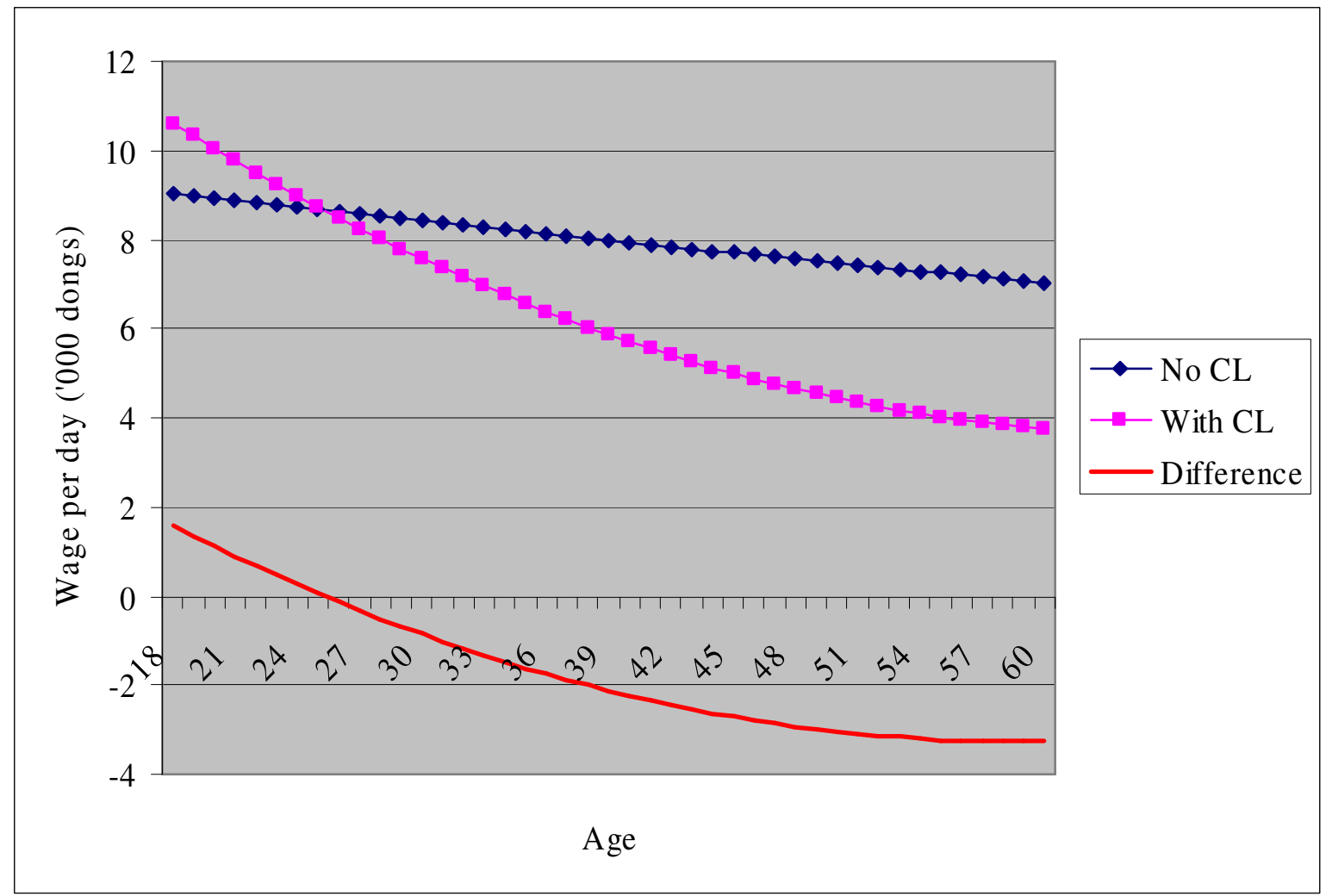




\section{Appendix: Estimating Shadow Wages}

As is typical of many developing countries, a large percentage of the workforce in our sample of rural households is engaged in self-employed agriculture rather than working for an observed wage. Instead of treating the wages of these self-employed farmers as zero, we estimate the opportunity cost of time for these workers. We follow Jacoby (1993) by estimating a shadow wage based on an agricultural production function. We assume that, in equilibrium, the shadow wage of each worker is the marginal product of labor in agriculture. We then estimate a farm production function that takes into account both labor and non-labor inputs:

$$
\ln \left(\text { revenues }_{i}\right)=\alpha+\sum_{k} \beta_{k} \ln \left(\text { expenditure }_{i k}\right)+\sum_{j} \gamma_{j} \ln \left(L_{i j}\right)+\mu X_{i}+\varepsilon_{i}
$$

where $k$ varies over the different types of expenditure (seeds, chemical fertilizers, manure, insecticides, transport, storage, rent, water) and $j$ captures variation over labor type (hired, exchange labor, family labor of males age 20 and greater, family labor of females age 20 and greater, family labor of males between age 12 and 19, and family labor of females between age12 and 19). Households are indexed by $i . X_{i}$ are household characteristics, including land holdings, and age and education of the household head. Revenues are calculated as the total value of crop and livestock output (including the amount consumed by the household) and twenty percent of the value of the household's livestock herd. The hourly marginal product of labor for each household is then obtained as:

$$
M P L_{i j}=\hat{\gamma}_{j} * \frac{\hat{Y}_{i}}{L_{i j}}
$$

where $\hat{Y}$ are predicted revenues and $L_{i j}$ is labor input for the various categories of family labor (female adult, male adult, male teenager, female teenager). This is finally normalized to obtain daily wages (expressed in 1,000 dongs). Individuals are assigned wages per day equal to daily wages when observed (i.e., for non-farm workers). Otherwise, wages per day are the shadow wage (daily marginal product defined above) for the same gender and age category. Results are reported in Appendix Table 1. 
Appendix Table: Production Function Estimates

\begin{tabular}{|c|c|}
\hline Variable & Coefficient \\
\hline \multicolumn{2}{|l|}{ LN (annual expenditures): } \\
\hline \multirow[t]{2}{*}{ seeds } & $-0.008 * * *$ \\
\hline & $(0.003)$ \\
\hline \multirow[t]{2}{*}{ chemical fertilizers } & $0.115^{* * *}$ \\
\hline & $(0.007)$ \\
\hline \multirow[t]{2}{*}{ manure } & $-0.014 * * *$ \\
\hline & $(0.003)$ \\
\hline \multirow[t]{2}{*}{ insecticides } & $0.055^{* * *}$ \\
\hline & $(0.005)$ \\
\hline \multirow[t]{2}{*}{ transport } & $0.009 * *$ \\
\hline & $(0.005)$ \\
\hline \multirow[t]{2}{*}{ storage } & $0.011 * * *$ \\
\hline & $(0.004)$ \\
\hline \multirow[t]{2}{*}{ rent } & $0.012 * * *$ \\
\hline & $(0.003)$ \\
\hline \multirow[t]{2}{*}{ other livestock activities } & $0.016^{* * *}$ \\
\hline & $(0.003)$ \\
\hline other aqua-culture activities & $0.049 * * *$ \\
\hline LN (annual labor hours): & $(0.003)$ \\
\hline \multirow[t]{2}{*}{ hired } & $0.090 * * *$ \\
\hline & $(0.006)$ \\
\hline \multirow[t]{2}{*}{ exchange } & $0.028 * * *$ \\
\hline & $(0.006)$ \\
\hline \multirow[t]{2}{*}{ family: males $20+$ years } & $0.043 * * *$ \\
\hline & $(0.003)$ \\
\hline \multirow[t]{2}{*}{ family: females $20+$ years } & $0.018 * * *$ \\
\hline & $(0.004)$ \\
\hline \multirow[t]{2}{*}{ family: male $12-19$ years } & $0.017 * * *$ \\
\hline & $(0.003)$ \\
\hline \multirow[t]{2}{*}{ family: female $12-19$ years } & $0.023 * * *$ \\
\hline & $(0.003)$ \\
\hline \multirow[t]{2}{*}{ LN (sq. meters of land) } & $0.111 * * *$ \\
\hline & $(0.008)$ \\
\hline \multirow[t]{2}{*}{ Age of household head } & $-0.003 * *$ \\
\hline & $(0.001)$ \\
\hline \multirow[t]{2}{*}{ Education of household head } & $-0.010 * *$ \\
\hline & $(0.004)$ \\
\hline Adjusted $\mathrm{R}^{2}$ & 0.66 \\
\hline Number of observations & 3465 \\
\hline
\end{tabular}

